\title{
Expectations of Domestic Tourists Before Destination Selection and Their Post-Purchase Evaluations: Igneada Case
}

\author{
Aydın ÜNAL \\ Kırklareli University, Pınarhisar Vocational School, Kırklareli, Turkey. \\ aydin-unal@hotmail.com.tr
}

\section{Onur CELEN \\ Bursa Uludag University, Harmancik Vocational School, Bursa, Turkey. onurcelen@uludag.edu.tr}

\begin{abstract}
In this study, it is intended to measure the pre-purchase expectations and post-purchase evaluations of domestic tourists who visited Igneada. For this purpose, a total of 250 questionnaires were delivered to the domestic tourists who were spending their holidays in the destination. The relevant destination was evaluated in terms of accommodation and food services, transportation services, general preservation and cleanliness, tourist activities and attractions, hospitality level and general tourist price level. As a result of the analyzes, it was determined that satisfaction evaluations were realized below the expectation levels in all the destination evaluation dimensions of the tourists visiting Igneada. In addition, it was found that the levels of overall satisfaction (48\%) and intention to revisit the destination (43.6\%) of the tourists were low.
\end{abstract}

Keywords: Tourism Marketing, Destination Marketing, Service Quality, Tourist Satisfaction, Igneada.

\section{INTRODUCTION}

The tourism industry is regarded as one of the strategic industries for developed and developing countries. At the basis of this view are elements such as the tourism industry providing dynamism to the economy by forming inter-sectoral connections, creating added-value, and offering employment opportunities (Martinez-Perez et al., 2019:80). For countries or regions to benefit from these positive contributions of tourism, they must possess touristic destinations that can allure prospective tourists. And for prospective tourists to evaluate the touristic destinations, factors such as the image they form in their minds, their previous experiences, and marketing efforts are determinant (Albert da Silva et al., 2018:93-94). Achieving the goals set in tourism destinations not only depends on destination planning and management, but also on how successful the implementation of marketing activities is. However, several difficulties such as learning the expectations and evaluations of tourists, measuring the general satisfaction and 
service quality, diversifying and positioning the destination, image, etc. are encountered in the destination marketing activities. While the number of destinations competing in the tourism markets is constantly increasing, the main differences perceived by tourists among these destinations tend to decrease. For this reason, the focus of the destination marketing strategy ought to be on establishing differentiation towards rival destinations in the perceptions of tourists, measuring expectations and evaluations, and strategic positioning. (Eren and Kozak, 2018:247). Even though differentiation, strategic positioning, advertisement, and all other marketing efforts are targeted mostly on alluring foreign tourists to the destination, assessing the expectations and post-purchase evaluations of domestic tourists in destinations is also an extremely important topic (Kweyne and Freimund, 2016:161-162). This is because the domestic market in tourism contributes directly and promptly to the dynamism of the local economy. By creating local segmentation in terms of destination marketing, it can be ensured for local tourists to get to know the different sub-parts of the main culture, experience social norms, lifestyles, and behaviors via domestic tourism movements (Shen et al., 2018:125).

\section{LITERATURE REVIEW}

The tourism marketing differs from the other marketing activities due to the nature of the products served to the tourists being abstract, the promotional activities being carried out by the state in a macro context and by tourism enterprises in the micro context, the destinations and touristic products being composed of too many elements, the subjective opinions being prevalent on the matter of the assessment of products and the services depending on the goods and services' incapability of being stored, and the tourist and the presented product and service being a total. In tourism marketing, the fundamental aspect that tourists evaluate their travels and the products and services they preferred is their experience. In the aforementioned experiences' perspective, whether tourists' perceptions match their expectations or not directly affects their level of satisfaction with their travels (Kozak, 2008:29-31; Halis and Turkay, 2009:415-416).

The studies in the domestic and foreign literature that examine the relationship between the expectations of tourists before the destination selection, as well as their evaluation after the purchase and the concerned evaluation and general satisfaction levels of tourists and their intentions of revisiting, are summarized below.

Chon and Olsen (1991) presented a connection between the visiting tourists' satisfactiondissatisfaction and both functional and symbolic evaluation accordance, in addition to setting forth the importance of perception-expectation levels of tourists in the destination in terms of showing their satisfaction or dissatisfaction levels via the study they conducted at Virginia, Norfolk with 382 participants. Tribe and Snaith (1998) utilized the HOLSAT scale to measure the holiday satisfaction of tourists in Cuba Varadero destination in their study with 102 participants, and they stated that tourists' satisfaction with their holiday experiences decreases should their perception about their holidays do not meet their expectations, and that positive perceptions can increase satisfaction. Kozak and Rimmington (2000), in a study they conducted with 220 British and German participants to measure the general satisfaction level of tourists visiting Mallorca during the winter season, concluded that meeting the tourists' expectations in the terms of destination components (attractions, hospitality, etc.) increased their satisfaction and in this case affected the tourists' intention to revisit the destination.

Atilgan et al. (2003), in a study they conducted with 100 German and 100 Russian participants who visited Antalya destination, asserted that to meet the high level of service quality at the destination, the expectations of the tourists should be determined and met fully, and that expectation maps was an important tool in terms of depicting the differences in service expectationperception of tourists. Ozturk (2004), in his study with 231 participants who visited Kizkalesi 
destination, stated that meeting the tourists' expectations in terms of destination components increased their general satisfaction level and their intention to revisit the destination. Yoon and Uysal (2005), in the study they conducted with 148 participants on the effects of motivation on destination satisfaction and commitment in the Turkish Republic of Northern Cyprus, expressed that tourists were affected by repellant-alluring factors in the destination, and the destination marketers taking these factors into account would contribute to the satisfaction that the tourists perceive from destination products and services, and also to the commitment they have for the destination.

As a result of the study conducted by Secilmis (2012) with 193 participants in Sakariilica destination to determine the connection between satisfaction and revisiting intention in the primary tourism destinations, he concluded that some of the destination components (accommodation facilities, etc.) affected the satisfaction and destination revisiting intentions at a low level, while some components (neatness, service quality, etc.) affected the satisfaction and destination revisiting intentions at a high level. Moutinho et al. (2012), in their study with 1,905 participants in Side-Manavgat destination, stated that the service quality in destinations was formed as the result of the perceived value of the destination and that this was a precursor to the thoughts of tourists. They also stated that the tourists satisfied with the destination gave advice after the destination experience and tended to buy again.

Khan et al. (2013), in their study with 300 participants in Malaysia, stated that there was a relationship between Muslim tourists' perception of destination image, religious motivation, and destination service quality and their satisfaction. Marin and Teberner (2013), in their study with 2,423 participants who visited Balearic Island, tried to determine the tourists' destination attitudes, satisfaction-dissatisfaction levels and their tendency to revisit the destination. Vetitnev et al. (2013), in their study with 1,100 participants in holiday destinations of Russia, stated that there was a relationship between the satisfaction of domestic tourists and destination commitment, and that the satisfied tourists tended to revisit the holiday destination. Rajaratnam et al. (2014), in their study with 309 participants in rural tourism destinations in Malaysia, concluded that the service quality perceived by tourists positively affected their satisfaction levels, and that there was a relationship between tourists' previous experiences about the destination and their perceived service quality and satisfaction. Beqiri et al. (2014), in their study with 87 participants in Velipoja destination in Northern Albania, stated that the service quality was effective in ensuring the satisfaction of tourists and their commitment to the destination, and that there was a positive relationship between tourists' satisfaction and their commitment to the destination. In the study Hau and Omar (2014) conducted in Rantau Abany, Malaysia with 165 participants to examine the effects of destinations' service quality on tourists' satisfaction, they concluded that many factors (destination image, supporting services and security, etc.) affected the satisfaction of tourists in destinations, and that there was a positive relationship between the provided service's quality and the tourists' satisfaction. According to the study conducted by Bjork and Kaupinnen-Raisanen (2016), it was concluded that tourists took various components (local food and cuisine culture, etc.) into account for their destination selection, and that satisfied tourists tended to prefer these destinations again.

\section{METHOD}

The main purpose of this study was to determine the differences between the expectations and experiences of domestic tourists regarding the services offered to tourists visiting Igneada destination and to evaluate the differences between these services and the demographic variables of domestic tourists, if any. In determining the relevant destination as the research area, various factors were effective such as the area being regarded as one of the important natural heritages 
of the world that should be protected, its being considered a unique ecosystem with its Longoz Forests (By the 13.11.2007 dated 26699 numbered No. 2001/12759 decision published in the Official Gazette, it has been declared as a National Park), its providing opportunity for a broad range of tourism diversity, especially but not limited to ecotourism, hunting tourism and cultural tourism, its proximity to populated cities such as Kirklareli $(97 \mathrm{~km})$, Tekirdag (145 km), Edirne $(165 \mathrm{~km})$ and especially Istanbul $(250 \mathrm{~km})$, and its annually increasing recognition and familiarity at a local and national scale (Igneada Municipality, 2019).

The number of studies examining the pre-purchase expectations and post-purchase evaluations of tourists in the tourism destinations, which constituted the purpose and the scope of the research, in terms of different and comprehensive dimensions is quite limited in the literature (Kozak and Rimmington, 2000; Kozak, 2001; Ozturk, 2004). The aforementioned studies were also utilized for creating the research model and questionnaire. The first part of the research questionnaire, which consists of two parts, includes 14 demographic questions and statements that the respondent can choose for these questions, and the second part of the questionnaire consists of a total of 48 statements ("strongly disagree" $(=1)$ to "strongly agree" $(=5)$ related to the dimensions in the research model. The research's demographic variables are composed of tourists' genders, marital status, age ranges, educational levels, occupations, monthly incomes, types of accommodation, the number of visits to the destination, the assessment level of their previous visits to the destination, their general acquaintance with the destination, the person or people they spend their holidays with, destination preference reasons, their general satisfaction levels with their holidays, and the intention of revisiting the destination. And as the destination service quality variables (Kozak, 2001), accommodation operations and catering services (AOCS), transportation services (TS), general cleaning and preservation (GCP), touristic activities and attractions (TAA), hospitality level (HL), and general touristic price level (GTPL) were assessed. Besides, the expectation levels and assessment levels of the tourists in terms of the destination service quality variables were also compared.

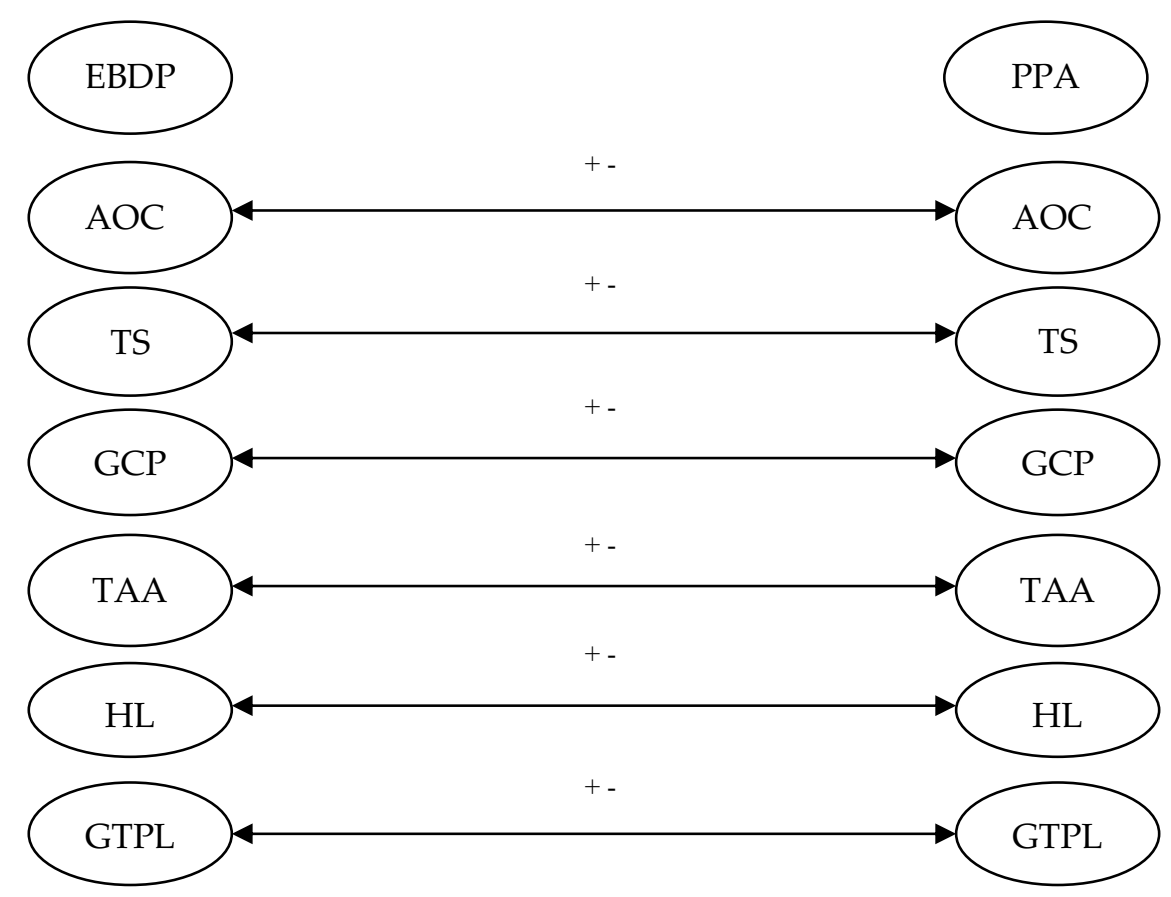

Figure 1: Domestic Tourists' Expectations Before Destination Purchase (EBDP) and Post-Purchase Assessments (PPA) Model 
Based on the relevant literature and the presented research model, it is thought that testing the following research hypotheses will contribute to a better understanding of the subject:

Hypothesis 1: The expectations and evaluations regarding the accommodation and catering services offered to domestic tourists at the destination demonstrate a significant difference.

Hypothesis 2: The expectations and evaluations regarding the transportation services offered to domestic tourists at the destination demonstrate a significant difference.

Hypothesis 3: The expectations and evaluations regarding the general cleanliness and preservation offered to domestic tourists at the destination demonstrate a significant difference.

Hypothesis 4: The expectations and evaluations regarding touristic activities and attractions offered to domestic tourists at the destination demonstrate a significant difference.

Hypothesis 5: The expectations and evaluations regarding the level of hospitality offered to domestic tourists at the destination demonstrate a significant difference.

Hypothesis 6: The expectations and evaluations regarding the general touristic price level offered to domestic tourists at the destination demonstrate a significant difference.

Hypothesis 7: The demographic variables of domestic tourists and the dimensions of the research demonstrate a significant difference.

The data collection process of the research was completed between May and September 2018, and a total of 250 questionnaires administered by the respondents were conducted via face-to-face communication with domestic tourists in the destination. For the determination of the people to whom the questionnaire would be administered, due to the advantage of time and cost, ease of access and the advantages of applying it to available or volunteer individuals, one of the nonprobabilistic paradigms, convenience sampling technique, was utilized (Erkus, 2011:106). 25 of the returned questionnaires were excluded from the assessment since more than $50 \%$ of the coding form was left blank. 225 questionnaires were included in the evaluation process of the study, and the return rate was $90 \%$.

After the research, the data obtained from the questionnaires were recorded on the computer, and a data set was established. The relevant data set was analyzed via the Statistical Package for the Social Science (SPSS) statistical data program, which is widely utilized in social sciences studies. The data related to the demographic variables of the domestic tourists obtained from the research questionnaire were analyzed with percentage and frequency values. The reliability of variables in the Likert type scale was analyzed via the utilization of the Alpha model. To perform a reliability analysis, there should be at least 20 statements and 50 subjects in the study (Ural and Kilic, 2005:258). The number of statements and subjects included in this study was sufficient to perform the relevant test. The Alpha value of the reliability analysis of the questionnaire, which was performed to test the reliability, was determined as 0.717 Alpha value demonstrates the total reliability level of the questions under the factor. In cases where this value is 0.70 and above, the research scale is considered reliable (Durmus et al., 2010:89). This result indicates that the research questionnaire is a reliable data collection tool. In this study, the face validity of the questionnaire was provided in the light of factor analysis results obtained from Kozak's (2001) study. In the study, the factor dimensions obtained in the original Kozak's (2001) study were used and included in the analyses.

Accordingly, Accommodation Operations and Catering Services (AOCS) dimension included the statements related to the overall service quality of the accommodation facility, the cleanliness of the accommodation facility, the safety of the accommodation facility, the accessibility of the accommodation facility, the activities of the accommodation facility, the check-in/out duration of the accommodation facility, the variety of food and beverage offered by the accommodation facility, the quality of the food and beverages offered by the accommodation facility, and the 
hygiene of the food and beverages provided by the accommodation facility. Transport Services (TS) dimension was composed of the statements related to the general ease of transportation to the destination, the ease of transportation to the historical and touristic areas in the destination, the ease of transportation to the sea and beach areas in the destination, the scope of the local transportation network at the destination, the comfort of the local transportation network at the destination, and the attitude of the officials who provide the local transportation at the destination. General Cleaning and Preservation (GCP) dimension consisted of the statements related to the cleanliness and appearance of the destination, the cleanliness of the sea in the destination, the cleanliness of the beaches in the destination, the cleaning and maintenance of the natural environment in the destination, the cleaning and maintenance of the historical and touristic areas in the destination, and the cleanliness and appearance of the tourism enterprises' officials in the destination. Tourist Activities and Attractions (TAA) dimension was composed of the statements related to the natural beauties and attractions in the destination, historical beauties and attractions in the destination, outdoor touristic activities conducted at the destination, indoor touristic activities conducted at the destination, climatic characteristics of the destination, tourism info services at the destination, local cultural characteristics of the destination, the variety of the cuisine culture in the destination, entertainment and excursion opportunities at the destination, touristic image and the recognition of the destination, nightlife opportunities at the destination, adventure and sports opportunities at the destination, shopping opportunities at the destination, variety of activities and services for children at the destination, the beauty of the landscape in the destination, and the adequacy of the health services in the destination. Hospitality Level (HL) dimension was composed of the statements related to the touristic atmosphere in the destination, feeling serenity at the destination, feeling safe at the destination, the attitude of the local people living in the destination towards tourists, the attitude of the touristic officials towards female tourists, and the attitude of the tradesmen in the destination towards tourists. General Touristic Price Level (GTPL) dimension was generally composed of the statements related to accommodation prices in the destination, prices of transportation opportunities, prices of food and beverages, prices of souvenirs, and the prices of entertainment facilities.

Besides, Independent-Samples T-Test (independent samples difference test) and One-Way ANOVA (one-way analysis of variance) were employed to measure the differences in demographic variables of domestic tourists in the context of relevant dimensions, and the Paired Samples T-Test (dependent sample difference test) was applied to detect differences between pre-purchase expectations and post-purchase evaluations. The t-test applied for the difference tests in the studies is utilized to determine whether or not there is a significant difference between the two groups' responses (Ural and Kilic, 2005:169). Levene test is applied before the application of the t-test to test the equality of the variances of the groups. If the Levene test, also known as the homogeneity test, is accepted, the calculated $t$ statistic value differs from the calculated $t$ statistic value when the Levene test is rejected.

While the t-test is utilized to compare the means of two independent groups, one-way analysis of variance for independent samples (ANOVA) is used to test whether or not the means of two or more groups with a single independent variable differ from each other. (Durmus et al., 2010:124). In this study, the t-test and the one-way analysis of variance were utilized to analyze the differences.

\section{RESULTS}

To make a general assessment of the demographic characteristics of the research participants, the frequency analysis was primarily performed and the results are given in Table 1. 
Table 1. Distributions Regarding Demographic Features $(n=225)$

\begin{tabular}{|c|c|c|c|}
\hline Demographic Characteristics & & Number & Percentage \\
\hline \multirow{2}{*}{ Gender } & Female & 106 & 47.1 \\
\hline & Male & 119 & 52.9 \\
\hline \multirow{2}{*}{ Marital Status } & Single & 77 & 34.2 \\
\hline & Married & 148 & 65.8 \\
\hline \multirow{3}{*}{ Age } & 15-24 Age Range & 29 & 12.9 \\
\hline & 25-60 Age Range & 139 & 61.8 \\
\hline & 61 Years and Older & 57 & 25.3 \\
\hline \multirow{5}{*}{ Educational Level } & Primary School & 19 & 8.4 \\
\hline & High School & 62 & 27.6 \\
\hline & Associate Degree & 45 & 20.0 \\
\hline & Bachelor's Degree & 74 & 32.9 \\
\hline & Postgraduate & 25 & 11.1 \\
\hline \multirow{5}{*}{ Occupation } & Student & 29 & 12.9 \\
\hline & Owner of the Business & 40 & 17.8 \\
\hline & Private Sector Employee & 55 & 24.4 \\
\hline & Public Employee & 53 & 23.6 \\
\hline & Retired & 48 & 21.3 \\
\hline \multirow{3}{*}{ Monthly Income } & 2,500TL and Less & 56 & 24.9 \\
\hline & Between 2.501TL-5.000TL & 105 & 46.7 \\
\hline & 5,001TL and Above & 64 & 28.4 \\
\hline \multirow{4}{*}{ Accommodation Type } & 5-Star Hotel & 67 & 29.8 \\
\hline & 3-Star Hotel & 45 & 20.0 \\
\hline & Apart Hotel & 42 & 18.7 \\
\hline & Hostel & 71 & 31.6 \\
\hline \multirow{2}{*}{$\begin{array}{l}\text { Number of Visits to } \\
\text { Destination }\end{array}$} & My First Visit & 156 & 69.3 \\
\hline & My Second Visit & 69 & 30.7 \\
\hline \multirow{3}{*}{$\begin{array}{l}\text { Destination Assessment } \\
\text { Level }\end{array}$} & First Time I am Visiting & 156 & 69.3 \\
\hline & Very Satisfied & 31 & 13.8 \\
\hline & Generally Satisfied & 38 & 16.9 \\
\hline \multirow{2}{*}{$\begin{array}{l}\text { Destination Recognition } \\
\text { Level }\end{array}$} & Very Familiar & 105 & 46.7 \\
\hline & I Have a General Opinion & 120 & 53.3 \\
\hline \multirow{6}{*}{$\begin{array}{l}\text { People You are Spending } \\
\text { Your Vacation With }\end{array}$} & I am Alone & 17 & 7.6 \\
\hline & With my Spouse & 64 & 28.4 \\
\hline & With my Spouse and Children & 55 & 24.4 \\
\hline & With my Family (Parents) & 29 & 12.9 \\
\hline & With my Girlfriend-Boyfriend & 23 & 10.2 \\
\hline & With My Friend Group & 37 & 16.4 \\
\hline \multirow{4}{*}{ Destination Choice Reason } & Close to Where I Live & 72 & 32.0 \\
\hline & Affordable & 57 & 25.3 \\
\hline & On Recommendation & 53 & 23.6 \\
\hline & Satisfied Before & 43 & 19.1 \\
\hline \multirow{2}{*}{ Overall Satisfaction Level } & Yes & 108 & 48,0 \\
\hline & $\mathrm{No}$ & 117 & 52.0 \\
\hline \multirow{2}{*}{ Intention to Revisit } & Yes & 98 & 43.6 \\
\hline & No & 127 & 56.4 \\
\hline & Total & 225 & 100 \\
\hline
\end{tabular}


Gender variable (t-test); except for the dimensions of AOCS expectation (.016), TS expectation (.045), TAA expectation (.044), and TS assessment (0.36), no significant difference was detected between the tourists' gender variable and the dimensions of the study. According to this, it was determined that in the dimension of AOCS expectation, female tourists $(\tilde{x}=39.77)$ compared to male tourists $(\tilde{x}=39.57)$, and again, in terms of TS expectation, female tourists $(\tilde{x}=26.70)$ compared to male tourists $(\tilde{x}=26.26)$ had higher levels of expectation. And as for TAA expectation dimension, it was determined that male tourists $(\tilde{x}=70.42)$ had higher levels of expectation compared to female tourists ( $\tilde{x}=70.28$ ). In TS assessment dimension, it was observed that female tourists' expectations ( $\tilde{x}=23.30)$ were met at a higher level compared to male tourists' expectations $(\tilde{x}=22.78)$.

Table 2. T-Test Analysis in Terms of Gender Variable

\begin{tabular}{|c|c|c|c|c|c|c|}
\hline \multirow[b]{2}{*}{ Factor } & \multirow[b]{2}{*}{ Groups } & \multirow[b]{2}{*}{$\tilde{\mathbf{x}}$} & \multicolumn{2}{|c|}{ Equality of Variance Test } & \multirow[b]{2}{*}{$\mathbf{t}$} & \multirow[b]{2}{*}{$\mathbf{P}$} \\
\hline & & & Levene & $\mathrm{p}$ & & \\
\hline \multirow{2}{*}{ AOCS Exp. } & Female & 39,77 & \multirow{2}{*}{,495 } & \multirow{2}{*}{,482 } & \multirow{2}{*}{2,651} & \multirow{2}{*}{,016 } \\
\hline & Male & 39,57 & & & & \\
\hline \multirow{2}{*}{ TS Exp. } & Female & 26,70 & \multirow{2}{*}{,008 } & \multirow{2}{*}{,927 } & \multirow{2}{*}{1,931} & \multirow{2}{*}{,045 } \\
\hline & Male & 26,26 & & & & \\
\hline \multirow{2}{*}{ TAA Exp. } & Female & 70,28 & \multirow{2}{*}{3,242} & \multirow{2}{*}{,073 } & \multirow{2}{*}{2,326} & \multirow{2}{*}{,044 } \\
\hline & Male & 70,42 & & & & \\
\hline \multirow{2}{*}{ TS Ass. } & Female & 23,30 & \multirow{2}{*}{ 319 } & \multirow{2}{*}{,573 } & \multirow{2}{*}{3,223} & \multirow{2}{*}{,036 } \\
\hline & Male & 22,78 & & & & \\
\hline
\end{tabular}

Marital status variable (t-test); except for GCP expectation (.044), HL assessment (.016), and GTPL assessment (.022) dimensions, no significant difference was observed between the tourists' marital status variable and the dimensions of the study. In the dimension of GCP expectation, it was determined that married tourists $(\tilde{x}=26.37)$ had higher levels of expectation compared to single tourists $(\tilde{x}=26.02)$. It was found that married tourists $(\tilde{x}=24.63)$ evaluated the HL assessment dimension more positively and at a higher level compared to single tourists ( $\tilde{x}=24.41)$, and similarly, married tourists $(\tilde{x}=16.52)$ evaluated the GTPL assessment dimension more positively compared to single tourists $(\tilde{x}=15.97)$.

Table 3. T-Test Analysis in Terms of Marital Status Variable

\begin{tabular}{|c|c|c|c|c|c|c|}
\hline & & & \multicolumn{2}{|c|}{ Equality of Variance Test } & \multirow[b]{2}{*}{$\mathbf{t}$} & \multirow[b]{2}{*}{$\mathbf{P}$} \\
\hline Factor & Groups & $\tilde{\mathbf{x}}$ & Levene & $p$ & & \\
\hline \multirow[t]{2}{*}{ GCP Exp. } & Single & 26,02 & \multirow{2}{*}{,250 } & \multirow{2}{*}{617} & \multirow{2}{*}{2,684} & \multirow{2}{*}{,044 } \\
\hline & Married & 26,37 & & & & \\
\hline \multirow[t]{2}{*}{ HL Exp. } & Single & 24,41 & \multirow{2}{*}{2,498} & \multirow{2}{*}{ 115 } & \multirow{2}{*}{2,821} & \multirow{2}{*}{,016 } \\
\hline & Married & 24,63 & & & & \\
\hline \multirow[t]{2}{*}{ GTPL Ass. } & Single & 15,97 & \multirow{2}{*}{1,783} & \multirow{2}{*}{ 183 } & \multirow{2}{*}{2,311} & \multirow{2}{*}{,022 } \\
\hline & Married & 16,52 & & & & \\
\hline
\end{tabular}

Number of visits to the destination variable ( $t$-test); except for the dimensions of AOCS expectation (.043), GCP expectation (.008), TAA expectation (.004) and HL assessment (.045), no significant difference was observed between the tourists' number of visits to the destination variable and the dimensions of the study. It was determined that the tourists who visited the destination for the second time $(\tilde{x}=40.05)$ had higher levels of expectation compared to tourists visiting for the first time ( $\tilde{x}=39.50)$ terms of AOCS expectation dimension; similarly, the tourists who visited the destination for the second time $(\tilde{x}=26.65)$ had higher levels of expectation compared to tourists visiting for the first time $(\tilde{x}=26.08)$ in terms of GCP expectation dimension; and likewise, the 
tourists who visited the destination for the second time $(\tilde{x}=71.30)$ had higher levels of expectation compared to tourists visiting for the first time $(\tilde{x}=69.94)$ in terms of TAA expectation dimension. It was determined that the tourists who visited the destination for the second time $(\tilde{x}=24.94)$ evaluated the HL assessment dimension more positively and at a higher level compared to tourists visiting for the first time $(\tilde{x}=24.39)$.

Table 4. T-Test Analysis in Terms of Number of Visits to the Destination

\begin{tabular}{|c|c|c|c|c|c|c|}
\hline \multirow{2}{*}{ Factor } & \multirow[b]{2}{*}{ Groups } & \multirow[b]{2}{*}{$\tilde{\mathbf{x}}$} & \multicolumn{2}{|c|}{ Equality of Variance Test } & \multirow[b]{2}{*}{$\mathbf{t}$} & \multirow[b]{2}{*}{$\mathbf{P}$} \\
\hline & & & Levene & $p$ & & \\
\hline \multirow{2}{*}{ AOCS Exp. } & My First Visit & 39,50 & \multirow{2}{*}{2,095} & \multirow{2}{*}{149} & \multirow{2}{*}{2,742} & \multirow{2}{*}{, 043} \\
\hline & My Second Visit & 40,05 & & & & \\
\hline \multirow{2}{*}{ GCP Exp. } & My First Visit & 26,08 & \multirow{2}{*}{5,876} & \multirow{2}{*}{,016 } & \multirow{2}{*}{2,666} & \multirow{2}{*}{,008 } \\
\hline & My Second Visit & 26,65 & & & & \\
\hline \multirow{2}{*}{ TAA Exp. } & My First Visit & 69,94 & \multirow{2}{*}{3,040} & \multirow{2}{*}{,083 } & \multirow{2}{*}{2,872} & \multirow{2}{*}{, 004} \\
\hline & My Second Visit & 71,30 & & & & \\
\hline \multirow{2}{*}{ HL Ass. } & My First Visit & 24,39 & \multirow{2}{*}{ 150 } & \multirow{2}{*}{ 699 } & \multirow{2}{*}{2,019} & \multirow{2}{*}{, 045} \\
\hline & My Second Visit & 24,94 & & & & \\
\hline
\end{tabular}

Destination recognition level variable ( $t$-test); except for the dimensions of AOCS assessment (.007) and TS assessment (.026), no significant difference was observed between the tourists' destination recognition variable and the dimensions of the study. It was observed that the tourists who had a general opinion about the destination $(\tilde{x}=35.45)$ evaluated the AOCS assessment dimension more positively and at a higher level compared to the tourists who stated that they knew the destination very well ( $\tilde{x}=34.74)$, whereas the tourists who stated that they knew the destination very well $(\tilde{x}=23.21)$ evaluated the TS assessment dimension more positively an at a higher level compared to tourists who had a general opinion about the destination $(\tilde{\mathrm{X}}=22.86)$.

Table 5. T-Test Analysis in Terms of Destination Recognition Level

\begin{tabular}{|c|c|c|c|c|c|c|}
\hline \multirow{2}{*}{ Factor } & \multirow[b]{2}{*}{ Groups } & \multirow[b]{2}{*}{$\tilde{\mathbf{x}}$} & \multicolumn{2}{|c|}{ Equality of Variance Test } & \multirow[b]{2}{*}{$t$} & \multirow[b]{2}{*}{$\mathbf{P}$} \\
\hline & & & Levene & $\mathbf{p}$ & & \\
\hline \multirow{2}{*}{ AOCS Ass. } & Very Familiar & 34,74 & \multirow{2}{*}{3,932} & \multirow{2}{*}{049} & \multirow{2}{*}{2,814} & \multirow{2}{*}{,007 } \\
\hline & I Have a General Opinion & 35,45 & & & & \\
\hline \multirow{2}{*}{ TS Ass. } & Very Familiar & 23,21 & \multirow{2}{*}{ 113 } & \multirow{2}{*}{ 737 } & \multirow{2}{*}{2,266} & \multirow{2}{*}{,026 } \\
\hline & I Have a General Opinion & 22,86 & & & & \\
\hline
\end{tabular}

Age variable (ANOVA); it was determined that in terms of AOCS expectation dimension (.027), the tourists between the ages of 25-60 ( $\tilde{x}=39.85)$ had higher expectations compared to tourists aged 61 and over $(\tilde{x}=39.45)$, and tourists between the ages of 15-24 ( $\tilde{x}=39.20)$. And in terms of HL expectation dimension (.030), it was determined that tourists between the ages of 15-24 ( $\tilde{x}=27.24)$ had higher expectations compared to tourists aged 61 and over $(\tilde{x}=26.35)$ and tourists between the ages of $25-60(\tilde{x}=26.31)$.

Table 6. ANOVA Analysis in Terms of Age Variables

\begin{tabular}{|c|c|c|c|c|c|c|}
\hline \multirow[b]{2}{*}{ Factor } & \multirow[b]{2}{*}{ Groups } & \multirow[b]{2}{*}{$\tilde{\mathbf{x}}$} & \multicolumn{2}{|c|}{ Equality of Variance Test } & \multirow[b]{2}{*}{$\mathbf{F}$} & \multirow[b]{2}{*}{$\mathbf{P}$} \\
\hline & & & Levene & $\mathrm{p}$ & & \\
\hline \multirow{3}{*}{$\begin{array}{l}\text { AOCS } \\
\text { Exp. }\end{array}$} & 15-24 Age Range & 39,20 & \multirow{3}{*}{817} & \multirow{3}{*}{,443 } & \multirow{3}{*}{2,381} & \multirow{3}{*}{027} \\
\hline & 25-60 Age Range & 39,85 & & & & \\
\hline & 61 Years and Older & 39,45 & & & & \\
\hline \multirow{3}{*}{ HL Exp. } & 15-24 Age Range & 27,24 & \multirow{3}{*}{, 525} & \multirow{3}{*}{,592 } & \multirow{3}{*}{3,573} & \multirow{3}{*}{,030 } \\
\hline & 25-60 Age Range & 26,31 & & & & \\
\hline & 61 Years and Older & 26,35 & & & & \\
\hline
\end{tabular}


Education variable (ANOVA); in terms of TS expectation dimension (.049), it was observed that tourists with high school education $(\tilde{X}=26.83)$ and associate degree $(\tilde{X}=26.80)$ developed a higher level of expectation compared to tourists with postgraduate $(\tilde{x}=26.56)$ and undergraduate degree $(\tilde{X}=26.02)$. It was determined that in terms of the GTPL expectation dimension (.013), the tourists with a postgraduate degree $(\tilde{X}=22.56)$ developed a higher level of expectation compared to tourists with primary school education $(\tilde{x}=21.57)$. And for the dimensions of GCP assessment (.033) and TAA assessment (.011), the tourists with primary school education (GCP: $\tilde{x}=24.05$; TAA: $\tilde{\mathrm{x}}=53.63$ ) evaluated more positively and at a higher level compared to tourists with high school education (GCP: $\tilde{\mathrm{x}}=23.25$; TAA: $\tilde{\mathrm{x}}=50.59$ ), associate degree (GCP: 23.06; TAA: $\tilde{\mathrm{x}}=50.93$ ), and postgraduate degree (GCP: 23.76; TAA: $\tilde{x}=50.64)$.

Table 7. ANOVA Analysis in Terms of Education Variables

\begin{tabular}{|c|c|c|c|c|c|c|}
\hline & & & Equality o & ance T & & \\
\hline Factor & Groups & $\tilde{\mathbf{x}}$ & Levene & $p$ & $F$ & $\mathbf{P}$ \\
\hline \multirow{5}{*}{ TS Exp. } & Primary School & 26,15 & \multirow{5}{*}{1,197} & \multirow{5}{*}{,313 } & \multirow{5}{*}{2,626} & \multirow{5}{*}{, 049} \\
\hline & High School & 26,83 & & & & \\
\hline & Associate Degree & 26,80 & & & & \\
\hline & Bachelor's Degree & 26,02 & & & & \\
\hline & Postgraduate & 26,56 & & & & \\
\hline \multirow{5}{*}{ GTPL Exp. } & Primary School & 21,57 & \multirow{5}{*}{1,935} & \multirow{5}{*}{, 106 } & \multirow{5}{*}{2,492} & \multirow{5}{*}{013} \\
\hline & High School & 22,41 & & & & \\
\hline & Associate Degree & 22,11 & & & & \\
\hline & Bachelor's Degree & 22,01 & & & & \\
\hline & Postgraduate & 22,56 & & & & \\
\hline \multirow{5}{*}{ GCP Ass. } & Primary School & 24,05 & \multirow{5}{*}{4,559} & \multirow{5}{*}{ 101 } & \multirow{5}{*}{2,310} & \multirow{5}{*}{,033 } \\
\hline & High School & 23,25 & & & & \\
\hline & Associate Degree & 23,06 & & & & \\
\hline & Bachelor's Degree & 23,82 & & & & \\
\hline & Postgraduate & 23,76 & & & & \\
\hline \multirow{5}{*}{ TAA Ass. } & Primary School & 53,63 & \multirow{5}{*}{2,054} & \multirow{5}{*}{,088 } & \multirow{5}{*}{4,341} & \multirow{5}{*}{011} \\
\hline & High School & 50,59 & & & & \\
\hline & Associate Degree & 50,93 & & & & \\
\hline & Bachelor's Degree & 52,13 & & & & \\
\hline & Postgraduate & 50,64 & & & & \\
\hline
\end{tabular}

Occupation variable (ANOVA); in terms of AOCS expectation dimension (.047), it was determined that the tourists who were self-employed $(\tilde{x}=39.95)$ developed a higher level of expectation compared to the tourists who were students $(\tilde{x}=39.44)$ and retired $(\tilde{x}=39.41)$, while the tourists who were public employees ( $\tilde{x}=26.49$ ) developed higher levels of expectation compared to tourists employed in the private sector $(\tilde{x}=26.29)$ and retired tourists $(\tilde{x}=26.16)$, in terms of HL expectation dimension (.040). And in terms of the GTPL expectation dimension (.010), it was determined that the tourists who were self-employed $(\tilde{x}=22.50)$ developed higher levels of expectation compared to tourists employed in the private sector $(\tilde{x}=21.89)$, and tourists employed in the public sector $(\tilde{\mathrm{x}}=21.77)$. 
Journal of Management and Economic Studies, vol.2, issue.2, pp.112-128

Table 8. ANOVA Analysis in Terms of Occupation Variables

\begin{tabular}{|c|c|c|c|c|c|c|}
\hline \multirow[b]{2}{*}{ Factor } & \multirow[b]{2}{*}{ Groups } & \multirow[b]{2}{*}{$\tilde{\mathbf{x}}$} & \multicolumn{2}{|c|}{ Equality of Variance Test } & \multirow[b]{2}{*}{$\mathbf{F}$} & \multirow[b]{2}{*}{$\mathbf{P}$} \\
\hline & & & Levene & $\mathrm{p}$ & & \\
\hline \multirow{5}{*}{ AOCS Exp. } & Student & 39,44 & \multirow{5}{*}{2,449} & \multirow{5}{*}{802} & \multirow{5}{*}{3,410} & \multirow{5}{*}{,047 } \\
\hline & Owner of the Business & 39,95 & & & & \\
\hline & Private Sector Employee & 39,72 & & & & \\
\hline & Public Employee & 39,75 & & & & \\
\hline & Retired & 39,41 & & & & \\
\hline \multirow{5}{*}{ HL Exp. } & Student & 27,20 & \multirow{5}{*}{2,042} & \multirow{5}{*}{, 120} & \multirow{5}{*}{2,854} & \multirow{5}{*}{, 040 } \\
\hline & Owner of the Business & 26,37 & & & & \\
\hline & Private Sector Employee & 26,29 & & & & \\
\hline & Public Employee & 26,49 & & & & \\
\hline & Retired & 26,16 & & & & \\
\hline \multirow{5}{*}{ GTPL Exp. } & Student & 22,51 & \multirow{5}{*}{3,408} & \multirow{5}{*}{, 068} & \multirow{5}{*}{2,222} & \multirow{5}{*}{,010 } \\
\hline & Owner of the Business & 22,50 & & & & \\
\hline & Private Sector Employee & 21,89 & & & & \\
\hline & Public Employee & 21,77 & & & & \\
\hline & Retired & 22,43 & & & & \\
\hline
\end{tabular}

Income variable (ANOVA); it was determined that in terms of AOCS expectation dimension (.008), the tourists with a monthly income of 5,001 TL and above $(\tilde{x}=39.96)$ developed a higher level of expectation compared to tourists with a monthly income of 2,501 TL-5,000 TL ( $\tilde{x}=39.61$ ), and tourists with a monthly income of $2,500 \mathrm{TL}$ and less ( $\tilde{\mathrm{x}}=39.42)$. In terms of TAA expectation (.039), it was determined that the tourists with a monthly income of 2,501 TL-5,000 TL ( $\tilde{x}=70.61)$ developed a higher level of expectation compared to the tourists with a monthly income of 2,500 TL and less $(\tilde{x}=69.73)$. It was observed that in terms of AOCS assessment dimension and TAA evaluation dimension (AOCS: .003; TAA: .005), the tourists with a monthly income of 2,501 TL and less (AOCS: $\tilde{x}=36.17$; TAA: $\tilde{x}=51.69$ ) evaluated more positively compared to the tourists with a monthly income of 2,501 TL-5,000 TL (AOCS: $\tilde{x}=35.00$; TAA: $\tilde{x}=51.60$ ), and the tourists with a monthly income of 5,001 TL and above (AOCS: $\tilde{x}=34.37$; TAA: $\tilde{x}=50.92$ ).

Table 9. ANOVA Analysis in Terms of Income Variables

\begin{tabular}{|c|c|c|c|c|c|c|}
\hline \multirow[b]{2}{*}{ Factor } & \multirow[b]{2}{*}{ Groups } & \multirow[b]{2}{*}{$\tilde{\mathbf{x}}$} & \multicolumn{2}{|c|}{ Equality of Variance Test } & \multirow[b]{2}{*}{ F } & \multirow[b]{2}{*}{$\mathbf{P}$} \\
\hline & & & Levene & p & & \\
\hline \multirow{3}{*}{ AOCS Exp. } & 2.500TL and Less & 39,42 & \multirow{3}{*}{4,960} & \multirow{3}{*}{,395 } & \multirow{3}{*}{2,933} & \multirow{3}{*}{,008 } \\
\hline & Between 2.501TL-5.000TL & 39,61 & & & & \\
\hline & 5.001TL and Above & 39,96 & & & & \\
\hline \multirow{3}{*}{ TAA Exp. } & 2.500TL and Less & 69,73 & \multirow{3}{*}{3,281} & \multirow{3}{*}{,259 } & \multirow{3}{*}{3,360} & \multirow{3}{*}{,039 } \\
\hline & Between 2.501TL-5.000TL & 70,61 & & & & \\
\hline & 5.001TL and Above & 70,48 & & & & \\
\hline \multirow{3}{*}{ AOCS Ass. } & 2.500TL and Less & 36,17 & \multirow{3}{*}{3,105} & \multirow{3}{*}{,470 } & \multirow{3}{*}{6,051} & \multirow{3}{*}{,003 } \\
\hline & Between 2.501TL-5.000TL & 35,00 & & & & \\
\hline & 5.001TL and Above & 34,37 & & & & \\
\hline \multirow[t]{3}{*}{ TAA Ass. } & 2.500TL and Less & 51,69 & \multirow{3}{*}{5,463} & \multirow{3}{*}{,380 } & \multirow{3}{*}{4,970} & \multirow{3}{*}{,005 } \\
\hline & Between 2.501TL-5.000TL & 51,60 & & & & \\
\hline & 5.001TL and Above & 50,92 & & & & \\
\hline
\end{tabular}

Accommodation type variable (ANOVA); it was determined that in terms of HL expectation dimension (.039), tourists who preferred apart hotel accommodation type $(\tilde{x}=27.09)$ developed 
higher levels of expectation compared to tourists who preferred five-star hotel ( $\tilde{x}=26.32)$ and a three-star hotel accommodation type $(\tilde{x}=26.06)$. And in terms of the GTPL assessment dimension (.004), it was detected that the tourists who preferred a three-star hotel $(\tilde{x}=16.68)$ and five-star hotel accommodation type $(\tilde{\mathrm{x}}=16.43)$ evaluated more positively compared to tourists who preferred apart hotel accommodation type $(\tilde{\mathrm{X}}=15.94)$.

Table 10. ANOVA Analysis in Terms of Accommodation Type Variables

\begin{tabular}{|c|c|c|c|c|c|c|}
\hline & & & Equality o & Test & & \\
\hline Factor & Groups & $\tilde{\mathbf{x}}$ & Levene & $\mathrm{p}$ & $\mathbf{F}$ & $\mathbf{P}$ \\
\hline \multirow{4}{*}{ HL Exp. } & 5-Star Hotel & 26,32 & \multirow{4}{*}{1,425} & \multirow{4}{*}{,236 } & \multirow{4}{*}{2,838} & \multirow{4}{*}{,039 } \\
\hline & 3-Star Hotel & 26,06 & & & & \\
\hline & Apart Hotel & 27,09 & & & & \\
\hline & Hostel & 26,40 & & & & \\
\hline \multirow{4}{*}{ GTPL Ass. } & 5-Star Hotel & 16,43 & \multirow{4}{*}{1,528} & \multirow{4}{*}{ 208 } & \multirow{4}{*}{2,079} & \multirow{4}{*}{,004 } \\
\hline & 3-Star Hotel & 16,68 & & & & \\
\hline & Apart Hotel & 16,45 & & & & \\
\hline & Hostel & 15,94 & & & & \\
\hline
\end{tabular}

Assessment levels of previous visits to the destination variable (ANOVA); it was determined that in terms of AOCS assessment dimension (.036) and TS assessment dimension (.041), the tourists who stated that they were very satisfied with their previous visit to the destination (AOCS: $\tilde{x}=35.61$; TS: $\tilde{x}=23.29$ ) evaluated more positively compared to the tourists who visited the destination for the first time (AOCS: $\tilde{x}=35.08$; TS: $\tilde{x}=22.99$ ), and tourists who stated they were overall satisfied with their previous visit to the destination (AOCS: $\tilde{x}=34.86$; TS: $\tilde{x}=22.97$ ).

Table 11. ANOVA Analysis in Terms of Assessment Level of Previous Visits to the Destination Variables

\begin{tabular}{|c|c|c|c|c|c|c|}
\hline \multirow{2}{*}{ Factor } & \multirow[b]{2}{*}{ Groups } & \multirow[b]{2}{*}{$\tilde{\mathbf{x}}$} & \multicolumn{2}{|c|}{ Equality of Variance Test } & \multirow[b]{2}{*}{$\mathbf{F}$} & \multirow[b]{2}{*}{$\mathbf{P}$} \\
\hline & & & Levene & $\mathrm{p}$ & & \\
\hline \multirow{3}{*}{ AOCS Ass. } & First Time I am Visiting & 35,08 & \multirow{3}{*}{3,383} & \multirow{3}{*}{, 556} & \multirow{3}{*}{2,588} & \multirow{3}{*}{,036 } \\
\hline & Very Satisfied & 35,61 & & & & \\
\hline & Generally Satisfied & 34,86 & & & & \\
\hline \multirow{3}{*}{ TS Ass. } & First Time I am Visiting & 22,99 & \multirow{3}{*}{3,251} & \multirow{3}{*}{,758 } & \multirow{3}{*}{3,277} & \multirow{3}{*}{041} \\
\hline & Very Satisfied & 23,29 & & & & \\
\hline & Generally Satisfied & 22,97 & & & & \\
\hline
\end{tabular}

Person or people with whom they were spending their holidays at the destination variable (ANOVA); it was observed that in terms of AOCS expectation dimension (.024), the tourists who were spending their holidays at the destination with their family (parents) $(\tilde{x}=39.93)$, with their girlfriend/boyfriend ( $\tilde{x}=39.69)$, with their spouse and children $(\tilde{x}=39.67)$, and only with their spouse $(\tilde{x}=39.64)$ developed a higher level of expectation compared to tourists who were spending their holidays with their friend group $(\tilde{x}=39.56)$ and alone $(\tilde{x}=39.52)$. And in terms of the GTPL expectation dimension (.048), it was determined that the tourists who were spending their holidays at the destination with their friend group $(\tilde{\mathrm{x}}=22.59)$ and alone $(\tilde{\mathrm{x}}=22.41)$ had higher levels of expectation compared to tourists who were spending their holidays with their spouse and children $(\tilde{\mathrm{x}}=22.03)$, with their girlfriend/boyfriend $(\tilde{\mathrm{x}}=22.00)$, and their families (parents) $(\tilde{\mathrm{x}}=$ 21.89). In terms of AOCS assessment dimension (.010), it was determined that the tourists who were spending their holidays at the destination with their spouse and children $(\tilde{x}=35.78)$, alone $(\tilde{\mathrm{x}}=35.29)$, and with their friend group $(\tilde{\mathrm{x}}=3524)$ evaluated more positively compared to tourists who were spending their holidays with their spouse $(\tilde{x}=34.84)$, and their girlfriend/boyfriend $(\tilde{x}=$ 
34.21). Besides, in terms of HL assessment dimension (.014), it was observed that the tourists who were spending their holidays at the destination with their friend group $(\tilde{x}=24.70)$, with their families (parents) $(\tilde{x}=24.68)$, and with their spouse and children $(\tilde{X}=24.63)$ evaluated more positively compared to the tourists who were spending their holidays with their spouse $(\tilde{x}=$ 24.50), with their girlfriend/boyfriend ( $\tilde{x}=24.43)$, and alone ( $\tilde{x}=24.17)$.

Table 12. ANOVA Analysis in Terms of the Person or People with Whom the Tourists Were Spending Their Holidays Together at the Destination Variables

\begin{tabular}{|c|c|c|c|c|c|c|}
\hline \multirow{2}{*}{ Factor } & \multirow[b]{2}{*}{ Groups } & \multirow[b]{2}{*}{$\tilde{\mathbf{x}}$} & \multicolumn{2}{|c|}{ Equality of Variance Test } & \multirow[b]{2}{*}{$\mathbf{F}$} & \multirow[b]{2}{*}{$\mathbf{P}$} \\
\hline & & & Lev. & $\mathrm{p}$ & & \\
\hline \multirow{6}{*}{$\begin{array}{l}\text { AOCS } \\
\text { Exp. }\end{array}$} & I am Alone & 39,52 & \multirow{6}{*}{2,656} & \multirow{6}{*}{,990 } & \multirow{6}{*}{2,110} & \multirow{6}{*}{, 024} \\
\hline & With my Spouse & 39,64 & & & & \\
\hline & With my Spouse and Children & 39,67 & & & & \\
\hline & With my Family (Parents) & 39,93 & & & & \\
\hline & With my Girlfriend-Boyfriend & 39,69 & & & & \\
\hline & With My Friend Group & 39,56 & & & & \\
\hline \multirow{6}{*}{$\begin{array}{l}\text { GTPL } \\
\text { Exp. }\end{array}$} & I am Alone & 22,41 & \multirow{6}{*}{1,600} & \multirow{6}{*}{, 527} & \multirow{6}{*}{2,833} & \multirow{6}{*}{, 048} \\
\hline & With my Spouse & 22,15 & & & & \\
\hline & With my Spouse and Children & 22,03 & & & & \\
\hline & With my Family (Parents) & 21,89 & & & & \\
\hline & With my Girlfriend-Boyfriend & 22,00 & & & & \\
\hline & With My Friend Group & 22,59 & & & & \\
\hline \multirow{6}{*}{$\begin{array}{l}\text { AOCS } \\
\text { Ass. }\end{array}$} & I am Alone & 35,29 & \multirow{6}{*}{1,822} & \multirow{6}{*}{,328 } & \multirow{6}{*}{2,163} & \multirow{6}{*}{,010 } \\
\hline & With my Spouse & 34,84 & & & & \\
\hline & With my Spouse and Children & 35,78 & & & & \\
\hline & With my Family (Parents) & 34,93 & & & & \\
\hline & With my Girlfriend-Boyfriend & 34,21 & & & & \\
\hline & With My Friend Group & 35,24 & & & & \\
\hline \multirow{6}{*}{ HL Ass. } & I am Alone & 24,17 & \multirow{6}{*}{2,939} & \multirow{6}{*}{,938 } & \multirow{6}{*}{3,253} & \multirow{6}{*}{,014 } \\
\hline & With my Spouse & 24,50 & & & & \\
\hline & With my Spouse and Children & 24,63 & & & & \\
\hline & With my Family (Parents) & 24,68 & & & & \\
\hline & With my Girlfriend-Boyfriend & 24,43 & & & & \\
\hline & With My Friend Group & 24,70 & & & & \\
\hline
\end{tabular}

Destination preference reasons variable (ANOVA); it was determined that in terms of AOCS expectation dimension (.044), the tourists who preferred the destination again due to their satisfaction with their previous visit $(\tilde{x}=39.81)$ and tourists who preferred it on recommendation $(\tilde{\mathrm{x}}=39.79)$ developed higher levels of expectation compared to the tourists who preferred it because it was affordable ( $\tilde{x}=39.31)$. In terms of TS expectation dimension (.011), it was determined that the tourists who preferred the destination again due to their satisfaction with their previous visit $(\tilde{x}=27.23)$ and tourists who preferred it because it was close to where they lived ( $\tilde{\mathrm{x}}=26.38$ ) had higher levels of expectation compared to tourists who preferred it because it was affordable $(\tilde{x}=26.29)$ and tourists who preferred it on recommendation $(\tilde{x}=26.16)$. And in terms of GTPL assessment dimension (.009), it was found that the tourists who preferred the destination on recommendation $(\tilde{\mathrm{x}}=16.84)$ and the tourists who preferred the destination again due to their satisfaction with their previous visit $(\tilde{x}=16.30)$ evaluated more positively compared to tourists who preferred the destination because it was affordable $(\tilde{\mathrm{x}}=15.94)$. 
Journal of Management and Economic Studies, vol.2, issue.2, pp.112-128

Table 13. ANOVA Analysis in Terms of the Destination Preference Reasons Variables

\begin{tabular}{|c|c|c|c|c|c|c|}
\hline \multirow[b]{2}{*}{ Factor } & \multirow[b]{2}{*}{ Groups } & \multirow[b]{2}{*}{$\tilde{\mathbf{x}}$} & \multicolumn{2}{|c|}{ Equality of Variance Test } & \multirow[b]{2}{*}{ F } & \multirow[b]{2}{*}{$\mathbf{P}$} \\
\hline & & & Lev. & $\mathrm{p}$ & & \\
\hline \multirow{4}{*}{ AOCS Exp. } & Close to Where I Live & 39,77 & \multirow{4}{*}{2,348} & \multirow{4}{*}{, 585} & \multirow{4}{*}{2,648} & \multirow{4}{*}{, 044} \\
\hline & Affordable & 39,31 & & & & \\
\hline & On Recommendation & 39,79 & & & & \\
\hline & Satisfied Before & 39,81 & & & & \\
\hline \multirow{4}{*}{ TS Exp. } & Close to Where I Live & 26,38 & \multirow{4}{*}{1,189} & \multirow{4}{*}{,315 } & \multirow{4}{*}{3,768} & \multirow{4}{*}{011} \\
\hline & Affordable & 26,29 & & & & \\
\hline & On Recommendation & 26,16 & & & & \\
\hline & Satisfied Before & 27,23 & & & & \\
\hline \multirow{4}{*}{ GTPL Asss. } & Close to Where I Live & 16,27 & \multirow{4}{*}{3,945} & \multirow{4}{*}{ 146 } & \multirow{4}{*}{2,701} & \multirow{4}{*}{,009 } \\
\hline & Affordable & 15,94 & & & & \\
\hline & On Recommendation & 16,84 & & & & \\
\hline & Satisfied Before & 16,30 & & & & \\
\hline
\end{tabular}

According to the result of the dependent sample t-test conducted to determine whether or not the dimensions related to the pre-purchase expectations of the domestic tourists included in the study and the dimensions of the post-purchase evaluation of the destination differed, it was determined that in all dimensions of the study (AOCS, TS, GCP, TAA, HL, GTPL), the assessment levels of domestic tourists were below their expectation levels.

Table 14. Gap Analysis of Tourists According to EBDP and PPA Dimensions

\begin{tabular}{|c|c|c|c|c|c|}
\hline Factor & Groups & $\tilde{\mathbf{x}}$ (Mean) & $t$ & $p$ & D-B \\
\hline \multirow{2}{*}{ AOCS } & Expectations (E) & 39,67 & \multirow{2}{*}{19,760} & \multirow{2}{*}{, 000 } & \multirow{2}{*}{$-4,55$} \\
\hline & Assessment (A) & 35,12 & & & \\
\hline \multirow{2}{*}{ TS } & Expectations (E) & 26,47 & \multirow{2}{*}{20,466} & \multirow[t]{2}{*}{, 000} & \multirow{2}{*}{$-3,44$} \\
\hline & Assessment (A) & 23,03 & & & \\
\hline \multirow{2}{*}{ GCP } & Expectations (E) & 26,25 & \multirow{2}{*}{18,586} & \multirow[t]{2}{*}{,000 } & \multirow{2}{*}{$-2,73$} \\
\hline & Assessment (A) & 23,52 & & & \\
\hline \multirow{2}{*}{ TAA } & Expectations (E) & 70,36 & \multirow{2}{*}{63,272} & \multirow[t]{2}{*}{, 000 } & \multirow{2}{*}{$-18,93$} \\
\hline & Assessment (A) & 51,43 & & & \\
\hline \multirow{2}{*}{ HL } & Expectations (E) & 26,44 & \multirow{2}{*}{11,295} & \multirow[t]{2}{*}{, 000} & \multirow{2}{*}{$-1,88$} \\
\hline & Assessment (A) & 24,56 & & & \\
\hline \multirow{2}{*}{ GTPL } & Expectations (E) & 22,16 & \multirow{2}{*}{38,417} & \multirow[t]{2}{*}{, 000 } & \multirow{2}{*}{$-5,83$} \\
\hline & Assessment (A) & 16,33 & & & \\
\hline
\end{tabular}

Domestic tourists' expectations of post destination purchase outweighed their assessments of post destination purchase in terms of accommodation and catering services ( $\tilde{x}=39.67>35.12)$, transportation services ( $\tilde{x}=26.47>23.03)$, general cleaning and preservation $(\tilde{x}=26.25>23.52)$, touristic activities and attractions $(\tilde{\mathrm{x}}=70.36>51.43)$, hospitality level $(\tilde{\mathrm{x}}=26.44>24.56)$ and general touristic price level $(\tilde{\mathrm{x}}=22.16>16.33)$, thus their the pre-purchase expectations of the destination could not be met. According to this result, all research hypotheses were accepted.

The following are the statements that constituted the dimensions of the research on which domestic tourists made the lowest-level evaluations: accessibility of accommodation businesses $(\tilde{\mathrm{X}}=3.83)$, check-in/out duration of accommodation facilities $(\tilde{\mathrm{X}}=3.85)$, the cleanliness of the sea at the destination $(\tilde{x}=3.76)$, the cleaning of the beaches at the destination $(\tilde{x}=3.88)$, natural beauties and attractions in the destination $(\tilde{x}=3.92)$, climatic characteristics of the destination $(\tilde{x}=3.86)$, local cultural characteristics of the destination $(\tilde{x}=3.88)$, adequacy of health services at the 
destination $(\tilde{\mathrm{X}}=3.80)$, feeling serenity at the destination $(\tilde{\mathrm{x}}=3.90)$ and feeling safe at the destination $(\tilde{x}=3.87)$. And the other research statements were evaluated close to or below the meeting of the expectations level by domestic tourists.

\section{CONCLUSION AND DISCUSSION}

The main purpose of this study was to determine the differences between the expectations and experiences of domestic tourists regarding the services offered to tourists visiting Igneada destination and to evaluate the differences between these services and the demographic variables of domestic tourists, if any. The important results obtained as a result of the analyses performed in this context are as follows:

In general, Igneada destination is visited by domestic tourists who are in the young and middleaged group (62\%), are with a monthly income of 2,501 TL and 5,000 TL (47\%), are mostly private and public sector employees $(48 \%)$, are traveling with their spouse $(25 \%)$ or both with their spouse and children (24\%), preferred the destination because it is close to where they live (32\%), and preferred the destination because it is affordable (25\%).

The destination for the vast majority of tourists $(69 \%)$ was their first visit. $52 \%$ of these tourists were generally not satisfied with their visit and stated that they would not intend to revisit (56\%). The rate of revisiting the destination was about 30\% among the tourists who left very satisfied with their previous visit or were generally satisfied with their previous visit. These results are valuable in terms of showing the existence and direction of the relationship between the overall satisfaction level with the destination and the intention to repurchase the destination. Accordingly, the general satisfaction level of the tourists affects the tourists' intention to visit the destination in direct proportion. These results are consistent with the results of the studies in the literature (Chon and Olsen, 1991; Tribe and Snaith, 1998; Kozak and Rimmington, 2000; Ozturk, 2004; Atilgan et al., 2004; Moutinho et al., 2012; Vetitnev et al., 2013; Beqiri et al., 2014; Beqiri et al., 2014; Bjork and Kaupinnen-Raisanen, 2016).

Among the visitors of the destination, female tourists compared to male tourists, tourists who were visiting for the second time compared to tourists who were visiting for the first time, the tourists with higher income compared to the tourists with lower income, and the tourists between the ages of 25-60 compared to tourists from other age groups had higher levels of expectation of accommodation services.

In terms of transportation services, tourists with undergraduate and postgraduate education had higher expectations than tourists in other education groups, and so did the male tourists compared to female tourists. In terms of assessing the dimension of hospitality, it was determined that tourists who visited the destination for the second time evaluated more positively than tourists who visited the destination for the first time, and so did the married tourists compared to single tourists.

Tourists with higher education levels evaluated the general cleaning and preservation services less positively. According to the assessment levels of domestic tourists included in the research, it was concluded that their pre-purchase expectations were not met in terms of accommodation, transportation, general cleanliness and preservation, touristic activities and attractions, hospitality, and touristic price levels. The studies that could be done to reverse this condition are of intense importance in terms of improving the image of the destination and enhancing the revisiting intentions of tourists (Chon and Olsen, 1991; Danaher and Arweiler, 1996; Tribe and Snaith, 1998; Khan, 2003; Frimpong Owusu et al., 2013).

It is thought that this study conducted shall contribute to the relevant destination, literature and future studies. Yet, the research could not be applied to a larger sample size due to financial 
resource impediments and time constraints. For this reason, increasing the nationality diversity of the tourists included in the study and broadening the sample size of the research in future studies would make a positive contribution in terms of the generalization of the study results. The scale applied in the research is quite comprehensive in terms of measuring the tourists' prepurchase expectations and post-purchase assessments of the destination. On the other hand, it would enable evaluating the destinations in terms of different variables via changes in demographic variables.

\section{REFERENCES}

Albert da Silva, M., Costa, R.A. and Moreira, A.C. (2018). The Influence of Travel Agents and Tour Operators' Perspectives on a Tourism Destination: The Case of Portuguese Intermediariers on Brazil's Image, Journal of Hospitality and Tourism Management, 34: 93104.

Atilgan, E., Akici, S. and Aksoy, S. (2003). Mapping Service Quality in the Tourism Industry, Managing Service Quality: An International Journal, 13(5): 412-422.

Bjork, P. and Kauppinen-Raisanen, H. (2016). Local Food: A Source for Destination Attraction, International Journal of Cotemporary Hospitality Management, 28(1): 177-194.

Beqiri, M., Borici, A., Borici, A. and Dergjini, A. (2014). An Empirical Study of Service Quality Factors Impacting Tourist Satisfaction and Loyalty: Velipoja Tourist Destination, TMC Academic Journal, 8(2): 36-48.

Chon, K. and Olsen, D.M. (1991). Functional and Symbolic Congruity Approaches to Consumer Satisfaction/Dissatisfaction in Tourism, Journal of the International Academy of Hospitality Research, 3: 2-20.

Danaher, J.P. and Arweiler, N. (1996). Customer Satisfaction in the Tourist Industry A Case Study of Visitors to New Zealand, Journal of Travel Research, 35: 89-93.

Durmus, B., Yurtkoru, E.S. and Cinko, M. (2010). Sosyal Bilimlerde SPSS'le Veri Analizi. 3. Edition, İstanbul: Beta Publishing.

Eren, S. and Kozak, N. (2018). Competitive Positioning of Winter Tourism Destinations: A Comparative Analysis of Demand and Supply Sides Perspectives-Cases From Turkey, Journal of Destination Marketing \& Management, 9: 247-257.

Erkus, A. (2011). Davranış Bilimleri İçin Bilimsel Araştırma Süreci. 3. Edition, Ankara: Seçkin Publishing.

Frimpong-Owusu, N., Nwankwo, S., Blankson, C. and Tarnanidis, T. (2013). The Effect of Service Quality and Satisfaction on Destination Attractiveness of Sub-Saharan African Countries: The Case of Ghana, Current Issues in Tourism, 16(7-8): 627-646.

Halis, M. and Turkay, O. (2009). Turizm İşletmelerinin Pazarlamasında Doğrulama (Confirmation), (Editor), Avcikurt C., Demirkol S. and Zengin B.: Turizm İsletmelerinin Pazarlamasında 7P ve 7C in (pp.399-418) İstanbul: Değişim Publishing.

Hau C.T. and Omar, K. (2014). The Impact of Service Quality on Tourist Satisfaction: The Case Study of Rantau Abang Beach as a Turtle Sanctuary Destination, Mediterrenean Journal of Social Science, 5(23): 1827-1832.

https://igneada.bel.tr/sayfa/tarihce/> [Available at: 20.08.2019].

Khan, M. (2003). Ecoserv: Ecotourists' Quality Expectations, Annals of Tourism Research, 30(1): 109124. 
Journal of Management and Economic Studies, vol.2, issue.2, pp.112-128

Khan, H.A., Hague, A., and Rahman, S.M. (2013). What Makes Tourists Satisfied? Empirical Study on Malaysian Islamic Tourist Destination, Middle-East Journal of Scientific Research, 14(12): 1631-1637.

Kozak, M. and Rimmington, M. (2000). Tourist Satisfaction with Mallorca, Spain, as an Off-Season Holiday Destination, Journal of Travel Research, 38: 260-269.

Kozak, M. (2001). Comparative Assessment of Tourist Satisfaction with Destinations Across Two Nationalities, Tourism Management, 22(4): 391-401.

Kozak, N. (2008). Turizm Pazarlaması. 2. Edition, Ankara: Detay Publishing.

Kweyne, J.M. and Freimund, W. (2016). Domestic Tourists' Loyalty to a Local Natural Tourist Setting: Examining Predictors from Retional and Transactional Perspectives Using a Zambian Context, Tourism Management Perspectives, 20: 161-173.

Marin, A.J. and Teberner, G.J. (2013). Satisfaction and Dissatisfaction with Destination Attributies: Influence on Overall Satisfaction and the Intention to Return. [Online] http://www.esade.edu/cedit/pdfs/papers/pdf6.pdf> [Available at: 12.09.2019].

Martinez-Perez, A., Elche, D. and Garcia-Villaverde, P.M. (2019). From Diversity of Interorganizational Relationships to Radical Innovation in Tourism Destination: The Role of Knowledge Exploration, Journal of Destination MarketingEManagement, 11: 80-88.

Moutinho, L., Albayrak, T. and Caber, M. (2012). How Far Does Overall Service Quality of a Destination Affect Customers' Post-Purchase Behaviours?, International Journal of Tourism Research, 14(4): 307-322.

Ozturk, B.A. (2004). Kızkalesi Yöresinde Tatilini Geçiren Turistlerin Memnuniyetlerini Etkileyen Faktörler, Unpublished Master's Thesis, Mersin University, Mersin.

Secilmis, C. (2012). Termal Turizm Destinasyonlarından Duyulan Memnuniyet Düzeyinin Tekrar Ziyaret Niyetine Etkisi: “Sakarılıca Örneği”, Elektronik Sosyal Bilimler Dergisi, 11(39): 231250.

Shen, Y., Joppe, M., Choi, H.C. and Huang, S. (2018). Domestic Tourism of Chinese in Canada: Distinct Differences. Journal of Destination MarketingEManagement, 8: 125-136.

Rajaratnam, D.S., Munikrishnan, T.U., Sharif, P.S., and Nair, V. (2014). Service Quality and Previous Experince as a Moderator in Determining Tourists' Satisfaction with Rural Tourism Destinations in Malaysia: A Partial Least Squares Approach, Procedia: Social and Behavioral Science, 144: 203-211.

Tribe, J. and Snaith, T. (1998). From Servqual to Holsat: Holiday Satisfaction in Varadero Cuba, Tourism Management, 19(1): 25-34.

Ural, A. and Kilic, İ. (2005). Bilimsel Araştırma Süreci ve SPSS ile Veri Analizi. Ankara: Detay Publishing.

Vetitnev, A., Romonova, G., Matushenko, N. and Kvetenadze, E. (2013). Factors Affecting Domestic Tourists' Destination Satisfaction: The Case of Russia Resorts, World Applied Sciebce Journal, 22(8): 1162-1173.

Yoon, Y. and Uysal, M. (2005). An Examination of the Effects of Motivation and Satisfaction on Destination Loyalty: An Structural Model, Tourism Management, 26(1): 45-56. 